\title{
THE FRACTAL PERSPECTIVE ON THE EVOLUTION OF THE PERIPHERAL URBAN FABRIC (BUCHAREST, ROMANIA)
}

\author{
Cirnu Lilian ${ }^{A}$ \\ Received: November 4, 2018| Accepted: April 25, 2019 \\ DOI: 10.5937/ZbDght1901016L
}

\begin{abstract}
This article presents the issue of contemporary urban dynamics, wherein urban sprawl occupies a central position. The post-Fordist city, an expression of individual initiative and piecemeal projects, decidedly favors this phenomenon, on the background of a constant rise in the social demand for individual housing. Faced with this new trend of extensive development, it is necessary to find ways of conciliating the categories of actors responsible for "creating the city", in the spirit of a sustainable, medium and long-term urban development, done, as far as possible, in the manner of an integrated approach. The perspective of the fractal modeling performed using the MUP City computer software may constitute an instrument which can be used in this context, putting forward a fractal reinterpretation of the principle of the garden-city.
\end{abstract}

Key words: urban sprawl, fractal urban fabric, MUP City

\section{INTRODUCTION - FROM THE DENSE TO THE DISPERSE CITY}

A densely populated city image has long been promoted as an effective solution to the space and energy overconsumption, favoring the use of public transportation, access to service provider hubs and social interaction - all this without directly emphasizing the negative effects of this approach, i.e. traffic congestion, the reduction of green areas or the increase in real-estate costs in the context of a reduced land resources (Tannier, 2009). Furthermore, the densely populated city risks a reappearance of the issues of the $18^{\text {th }}-19^{\text {th }}$ century European city, which lacked adequate fresh air circulation and natural lighting. An alternative to this, along with avoiding anarchic urban development, would be adopting a polycentric city or polycentric urban concentration pattern, a model akin to the model of the fractal city (Frankhauser, et al., 2010).

\footnotetext{
A University of Bucharest, Faculty of Geography, Bucharest, Romania; contact: cirnu_lilian@yahoo.fr
} 
Applying the principles of a dense city on the scale of an urban agglomeration is illogical due to the spatial reality, i.e. built-up and empty areas alternate both at the neighborhood and at an urban agglomeration level. The presence of undeveloped spaces inbetween built elements represents a factor which facilitates the movement of individuals and the circulation of air masses. If the individuals' access to green areas is enabled in a compact city with a reduced built area, as this built area and the city grow, the only solution is to integrate those green areas into the city. One of the best known examples is the one taken from T. Sievert's "Cities Without Cities" (2003), wherein it is stated that at the end of the $19^{\text {th }}$ century it was still possible to reach the edge of the city, without too much effort, either on foot or by bike, which was the element that encouraged the development of a compact urban fabric.

Subsequently, as the city started to grow at a sustained rate, a tentacular development emerged, which ensured a comparable degree of access to green areas. After all, the alternation of built-up areas and green spaces is not a new phenomenon in urban dynamics, since they have existed since Antiquity (for instance the patricians' villas surrounding Rome) and continued to be used in the $20^{\text {th }}$ century, through the "garden-city" movement or through the principles of the Athens Charter (Benevolo, 1994).

Furthermore, as a result of the diverse professional activities and the inhabitants' commuting trajectories, these trajectories are no longer limited just to going from home - to commercial hubs - to workplace, but include an ever-increasing demand of access to the green areas and recreation spaces on the outskirts of cities. This trend contributes to a progressive elaboration of a complex relation between constructed and free spaces found within and on the outskirts of the urban fabric. In this context, "creating the city" becomes a process of auto-organization in relation to "empty" spaces (Frankhauser, Ansel, 2012). We must make a distinction between the urbanization "with holes" or in "flea-jumps" found in the French literature (Castel, 2007) and the "leapfrogging or urban sprawl" of the Anglo-Saxon literature. Urbanization using free spaces is a result of the inhabitants' desire of enjoying easier access to green spaces, not necessarily of a speculative real estate land policy.

Additionally, the change of paradigm during the conception of urban spaces has played a decisive role in this transition from the dense to the sprawled city. We are thus moving from o vision characteristic of the Fordist city, (built on account of the rural exodus and in the context of mass-production, involving an implicit requirement of providing lodgings for a large number of inhabitants), to a post-Fordist type of city which comes to the fore with the change of industrial economic profiles in 1980s Western Europe. The latter model is characterized, among other things, by the urban sprawl phenomenon, and by the multiplication of the types of habitat or even of the types of the Single-family detached homes (Berque, et al., 2006). 


\section{THE BUCHAREST SUBURBIA - ELEMENT OF INTERFERENCE BETWEEN VARIOUS ACTION PATTERNS}

The main challenge in the setting up of peripheral urban areas is finding a common denominator between the aspirations of those who wish to settle outside the city, in a semi-rural environment, and the authorities' intentions of managing these extensions in a rational/sustainable manner.

After zooming in on this issue concerning the Bucharest suburbs (Romania), pertaining particularly to the case of Pantelimon, Ilfov County, several pertinent points of view are brought out.

For instance, there is a very strong social demand for an alternative to collective housing, with the entire plethora of motivations which underpin it (Cîrnu, 2013a). Those who live in the suburbs of Bucharest are seeking superior housing quality, in order to provide a more generous habitable space to the city apartment, as well as a secure space where family life might unfold in peace and intimacy. On the other hand, searching for an area resembling a semi-rural environment in the vicinity of nature, they are forced, via the logics of land use economics, to stray farther from the service provider centers and from the main axes of public transportation. When interviewed, "neo-rural inhabitants" of Pantelimon gave precisely these answers (Cîrnu, L, 2013b). This is indirectly reflected in the local authorities' inability of supporting the extension of public utility networks to cover a new urban fabric which is continuously expanding in discontinuity with the core or the city. The solution of the dense city seems not to work from this point of view, given the fact that many of those who have chosen to settle in the suburban areas have done rejecting the constructed density of the Communist era. It has been proven that low density considerably impacts the inhabitants' health (Braubach, 2007), as well as neighborly relations (Andersen, 2008) and also the real estate market value (Bolitzer, Netusil, 2000).

Thus, real estate developers offer the most profitable product - the single-family detached home, which is easiest to build and which involves the use of elementary resources and low risk of retention.

Facing these issues, the local authorities of the communes surrounding Bucharest fully support this process, for various reasons. Firstly, there are those we shall call "objective reasons". In Pantelimon, the elected officials wish to strengthen the township's urban appearance through drawing in an ever-larger number of new inhabitants. Leases of public residential land are being granted and not just to former township inhabitants who wish to move back in.

In the local newspaper ${ }^{1}$, an intention was expressed to reduce the agricultural areas, seen as a stigma, a reminder of the agricultural profile of the ancient rural Pantelimon. Furthermore, attracting new population, mostly young and middle-age families with underage children, encourages the maintenance of the town's public assets and contributes to the development of new ones, such was the case with "Rugby Club Pantelimon", made up of children younger than 14, which has contributed to the township's prestige through its sport results. The influx of new population is also felt at the local budget lev-

\footnotetext{
${ }^{1}$ http://www.jurnaluldeilfov.ro/stiri-locale/pantelimon.html
} 
el, through the collected taxes, but also indirectly through the maintenance of services and proximity commerce, or through modifications at the social level: the Roma ethnics and the socially assisted population is lowering in percentage, and thus, Pantelimon's outward image is progressively changing. Local authorities support the development of the real estate sector in the area, the main criteria being the cash entries resulting from authorizations granted, rather than supposed future investments to be made. A telling example of this policy is the Local Council ruling Nr. 4 of 23.01.2002, which, only two years after the sanctioning of the new Master Plan which envisaged the tripling of the inner-city surface perimeter, modified the authorized construction parameters stipulated in that regulation, by going from a maximum POT (Potential of Land Occupation) of $20 \%$ to a POT of $45 \%$, precisely in order to stimulate the real estate sector.

There is also a series of motivations deemed as "subjective", peripheral, underscored by relations which are at the edge of legality, and beyond it; relations between the local elected officials, the public administration and various economic actors with interests vested in the town's real estate market.

Considering this entire relational system which evidently supports the development of this phenomenon, with its flaws and problems, the central authorities (the Ministry of Regional Development and Public Administration) and their subordinate structures, aware of those anomalies which take root within the confines of this phenomenon, are attempting to remediate the situation through regulatory texts (for example, O.G. 7/2011, which addresses this issue specifically) and through actions meant to raise the local officials' awareness to the nature of these urban dynamics.

How could this dilemma be solved? A possible answer may stem from the simulations performed by the team coordinated by Pierre Frankhauser at the ThéMa laboratory, which has demonstrated the advantages of a fractal-type structure in contrast with a dense urban fabric or with an insufficiently framed single-family detached home urban fabric, developed mainly at the piecemeal initiative of those who wish to settle outside the city.

\section{MUP CITY. INSTRUMENT OF FRACTAL MODELING ON THE URBAN FABRIC}

This simulation program, created in 2010, combines the principles of fractal modeling with GIS techniques, as a reinterpretation of Walter Christaller's 1930s theory of central places. The fractal theory of urban modeling predicts modifications to this theory, introducing the requirement of conserving green inroads within the urban fabric (Fig. 1).

This perspective upon the development of suburban areas maintains that the limitation of the inhabitants' mobility is not confined to the difficulty in accessing the recreational areas or to an axial organization of transportation; what is also needed is a hierarchical organization of service provider hubs, meant to cater to various levels of an agglomeration. This principle was put into practice in Great Britain, in the setting up of the "urban villages" (Thomas, et al., 2008). 


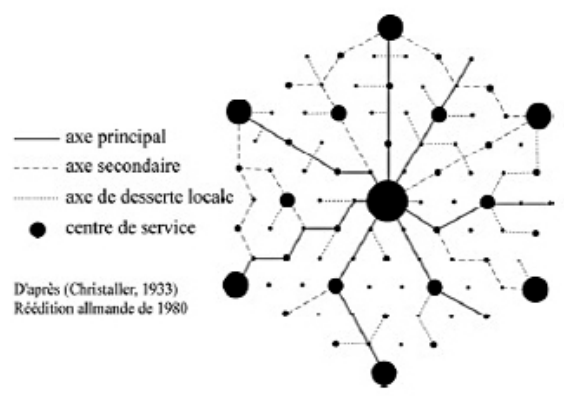

(a)

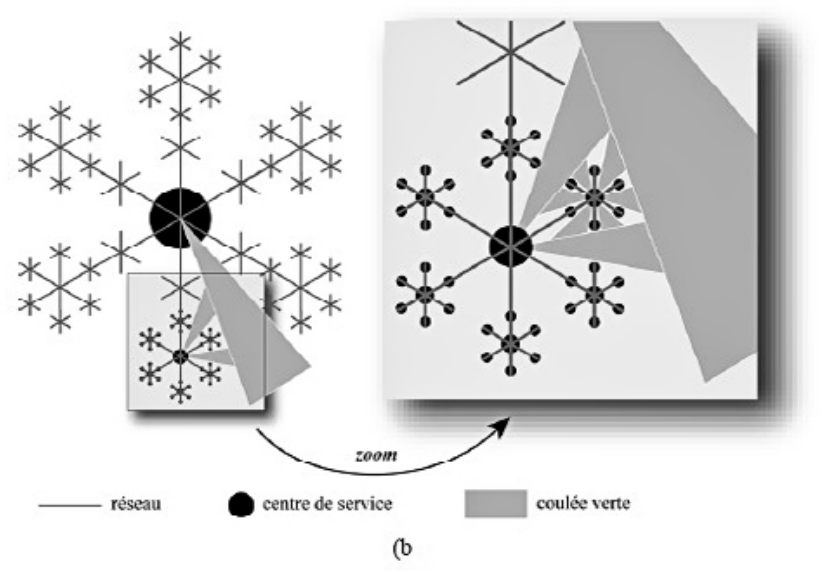

Figure 1. The reinterpretation of the theory of central places through the insertion of green inroads

Source: Pierre Frankhauser, C. T., Gilles Vuidel, Hélène Houot (2007). Approche fractale de l'urbanisation. Méthodes d'analyse d'accessibilité et simulations multi-échelles. 11th World Conference on Transportation Research. Berkeley: 21

\section{THE MUP CITY SOFTWARE. OPERATING PRINCIPLES.}

Based on this polycentric-fractal perspective of territorial and urban space organization, in the year 2010, within the ThèMA research centre, Université de Franche Compté, a modelling program was developed which emphasizes access to services while still preserving the inner green areas and favoring the mitigation of commutes.

The four major principles of operation in MUP City are the following (Tannier, 2009):

- Ensuring a good degree of inhabitant access to services and green areas.

- Avoiding the fragmentation of natural or agricultural space, aiming to conserve the biological and landscape diversity of the site. This guiding principle is also conducive to the streamlining of the common transportation network.

- The reduction of the space taken up by new elements of infrastructure, by channeling urbanization along the vectors of the extant transportation grid. 
- The preservation and development of green area inroads into the built areas, due to hygiene reasons (enhancing the penetration of fresh air hailing from the green areas), and in order to highlight the landscape value of the site.

These four major principles are complemented by a fractal rule of urbanization and by four more additional rules of accessibility.

The fractal rule (Tannier et al., 2010) of urbanization is based on a relation of the type $D=\log N / \log r$, where $D$ is the fractal dimension, $N$ is the number of urbanized cells and $r$ is the reduction factor of the aforementioned cells, from one scale of analysis to another (Tannier, et al. 2010). This fractal rule imposes a statistical auto-similarity upon the newly built areas, one according to which the aggregates, as well as the empty spaces (natural areas/green areas) need to be distributed uniformly in the territory. The decomposition into a fractal grid, leads to a quasi-total auto-assimilation of the elements. Through the implementation of this rule, we can identify the number of potentially built cells existing within each "box" of the decomposition grid.

\section{IDENTIFYING THE POTENTIAL OF URBAN EXTENSION, FROM A FRACTAL PERSPECTIVE}

For the township of Pantelimon, this method of simulation based on the fractal logics was implemented in several stages. Firstly, drawing upon the township's 1990 cadastral papers, scaled 1:2000 and upon the aerial images of 2010, as cartographical basis, the built footprint of the existent edifices was extracted.

Subsequently, the existent streets were extracted, as well as those approved through the Local Master Plan (PUZ) accepted throughout the 2000 - 2010 period, though not actually put into practice yet. Three main types of spaces were taken into account as being areas non aedificandi: the water surface of Lake Pantelimon and the forested areas (Cernica Forest, Pustnicu Forest) were assessed, in order to preserve the landscape value of the site and to encourage the preservation of biodiversity. To these natural areas were added the perimeters of the military installations (7-8 Battery, Fort VII Pantelimon, Fort VII Cernica - in the Belt Road area, the Military Barracks situated between Tractorului and Răscoalei streets) which, though largely abandoned, are situated on lands belonging to the National Defense Ministry and are therefore, at the moment, restricted areas in terms of civil purposes.

The service provider centers and commercial hubs required for establishing the levels of accessibility were equally identified (Fig.2) These were, in part, pinpointed by means of on-site prospection, the collected information having been subsequently complemented by consulting specialized directories (such as the Golden Pages, White Pages, Yellow Pages) and located by means of the Wikimapia (wikimapia.org) or Google Earth (googleearth.com) services. Three levels of serviceability were established, in accordance with the previously described methodology, and the identified centers were coded into 20 categories. 


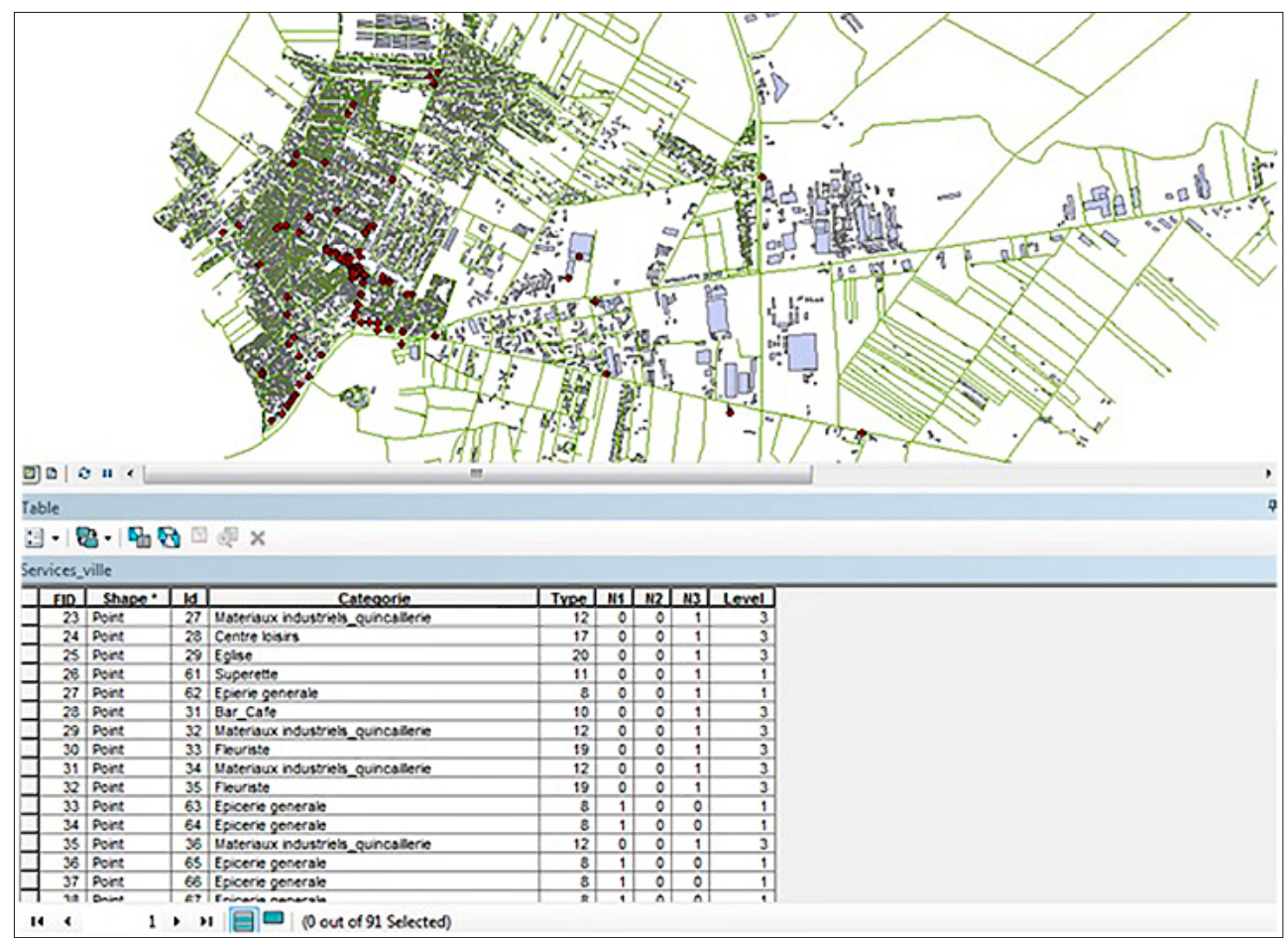

Figure 2. The identification and coding of service provider hubs using the ArcGis softwear

All this data was referenced into the Stereo 70 national coordination system, datum Dealul Piscului 1970.

In an initial stage, the respective data set was keyed into the MUP City program, layer by layer, with all the complementary information. Afterwards, the option of multihierarchical decomposition of the aforementioned layers was launched, taking into account a reduction factor of $1 / 3$, with a minimal cell size of $20 \mathrm{~m}$, so as not to infringe upon urban microstructure. The density corresponding to the cells which are about to be urbanized equals zero, i.e. the program will only accept into the simulation's calculation those cells which do not, at present, contain any constructed element (with the obvious exception of communication paths). The maximum size of the cell side, following the decomposition of the perimeter of study, is of $1620 \mathrm{~m}$.

\section{The strict fractal development scenario}

Firstly, a strict fractal scenario was set up, with a maximum number of 5 constructed cells within a superior size cell (Fig. 3). An analysis performed using a given cell-side size of $540 \mathrm{~m}$ revealed that the areas with a development potential from the perspective of strict fractal patterns are situated in the prolongation of the urban fabric present in the town center area. The more pronounced the shade of red is, the closer each cell is to a score of 1 , and therefore, the better its prospects for building. 


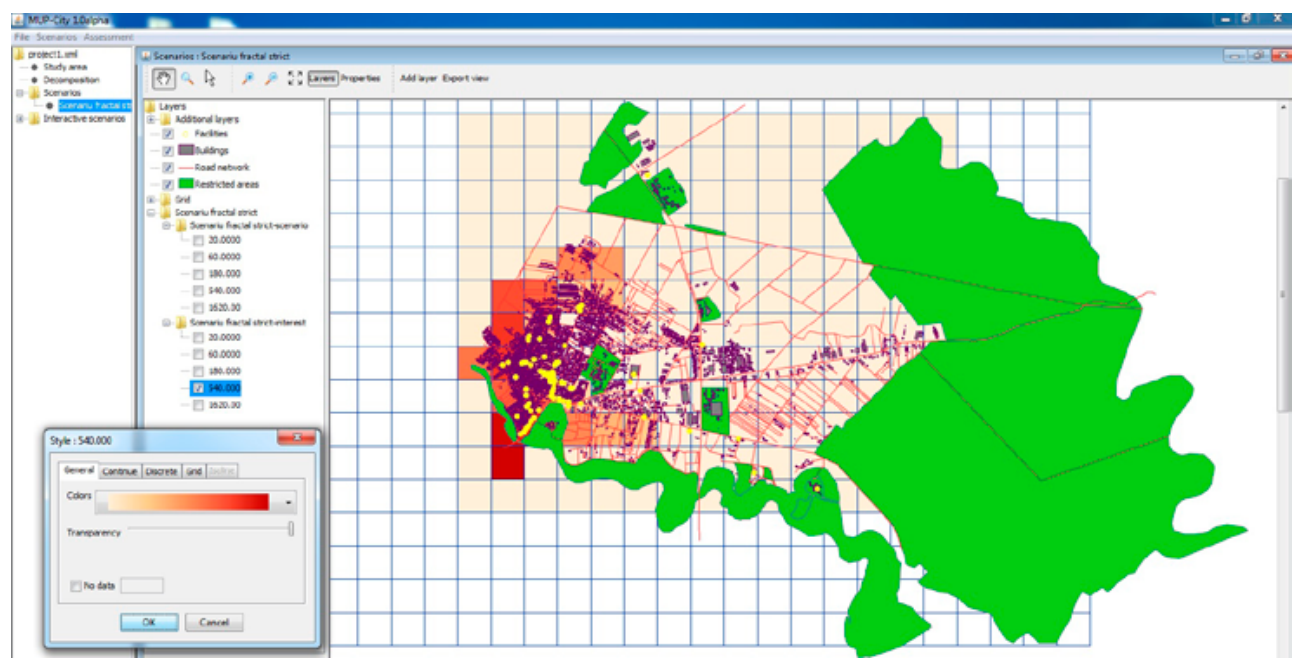

Figure 3. Analysis of the urbanization potential of the urban fabric extant in Pantelimon, Ilfov county in 2010, given a cell size of $540 \cdot 540 \mathrm{~m}^{2}$

As we reduce the size of the cells, the analysis becomes more exact. At a cell size of $400 \mathrm{~m}^{2}(1=20 \mathrm{~m})$, which corresponds to a minimal size of the developed parcel so as not to over-fragment the urban fabric in the suburban area, the details obtained are very precise, to the point where one may establish the optimal position of implantation of every house.

\section{The non-fractal development scenario}

The second stage consisted in using the MUP City software in order to generate a non-fractal simulation scenario. This scenario is based on the previously inputted codifications, without, however, following a fractal distribution of aggregates, nor a hierarchic classification of the inner unconstructed spaces. For the same perimeter of investigation, given a cell size of $540 \mathrm{~m}$ and aiming for the identification of cells with a high potential of urbanization, one notices a great concentration of high potential around the township center, a situation similar to the first type of modeling.

However, on a scale of analysis employing a cell side of $20 \mathrm{~m}$ (400 $\mathrm{m}^{2}$ in surface), major differences between the two proposed models come to light: in this latter case we are dealing with a process of continuous urbanization, which develops being exclusively grafted onto the existing constructions and communications network. This model, lacking a fractal rule, pays no heed to the preservation of the unconstructed areas meant as inroads of green areas within the constructed urban fabric. A telling example in support of this conclusion is the urbanization potential having been identified by the two scenarios around the "Selgros Pantelimon" commercial center (Fig. 4).

In the first scenario, based on a strict fractal rule of urbanization, one can see how an area with certain urbanization potential is simultaneously grafting itself onto the extant constructed fabric, and onto the communications network, exhibiting a continuous aspect and preserving spaces meant for the penetration of green areas. 


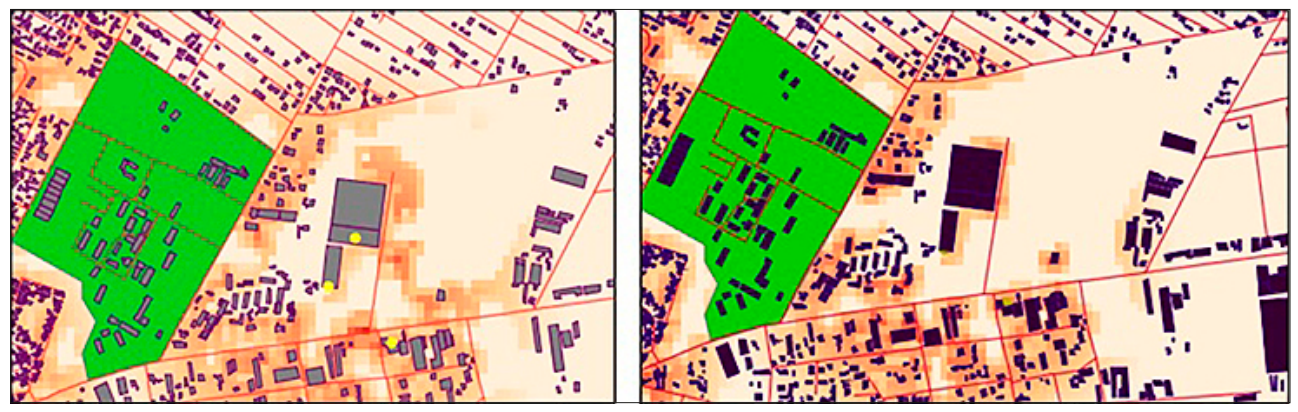

Figure 4. Identifying the urbanization potential following a strict fractal scenario (on the left) and a non-fractal scenario (on the right) in the area of the "Selgros Pantelimon"

commercial centre

In the second case we notice the interest displayed towards grafting onto an existent tissue and onto the previously developed streets, which, in the case of a suburban urban fabric such as the areas developed in Pantelimon after 1990, would generate, at the corresponding scale of analysis, a perpetuation of the previously exhibited tendency towards fragmentation. We must, however, take note of the fact that both scenarios identify areas susceptible to residential urban development in the proximity of the town's main center, which is better served in terms of public services and proximity trade; this goes directly against the directions of development favored by Pantelimon City Hall, which has been, and is still granting derogations from the urbanism regulations, and giving authorizations of construction in perimeters located along the Cernica highway or along Biruinței Boulevard - that is to say, considerably far removed from the city center.

\section{The interactive scenario}

The down side of the two previously discussed simulation models is the global manner in which urbanization is considered, without offering the decision makers any opportunity to center themselves, i.e. to choose a certain direction of urbanization. This potential shortcoming is eliminated through the possibility of elaborating an interactive urbanization simulation, one based, however, in turn, upon a fractal-type distribution of elements.

Thus, we put forward the hypothesis that, after a period when the process of expansion of the built-up areas has developed anarchically, we witness to a transition towards a strict management of this phenomenon, the local officials' attention now focusing towards the township's center, where there is a dense network of roads, close to the service providers and trade centers. From this perspective, the main direction of urbanization would be towards the West of this area, following fractal logic of distribution of newly constructed areas. A 4 ha extension of the constructed area is to be desired, which would ensure the necessary land resource for approximately 100 individual residences. At the aforementioned scale of analysis $\left(180 \cdot 180 \mathrm{~m}^{2}\right) 4$ cells with relatively high urbanization potential were identified, the construction of which is tentatively being stimulated. Not all the identified cells may be constructed because the previously established 
rules would thereby be broken. In such cases, the software program displays the message "The number of constructed cells within the grid pattern has already reached its maximum", or "The construction of the cell would prevent an inroad of green space".

Fractal multi-hierarchic logic also makes it so that at an inferior scale (as far as cell size goes), the cells may be constructed only if the superior fractal cell wherein they are included has in turn been built, in order to prevent the useless consumption of good urban lands.

Therefore, out of the four cells which are potentially constructible, only one simultaneously fulfills the imposed conditions. By increasing the scale of analysis, however, the number of cells within the targeted perimeter which are interesting from an urbanization perspective grows. Given a cell size of $60.60 \mathrm{~m}^{2}$, another 11 cells are added to the 5 previously urbanized cells (a cell of $180 \cdot 180 \mathrm{~m}^{2}=9$ cells of $60 \cdot 60 \mathrm{~m}^{2}$, with a maximum number of 5 urbanized cells). The other ones having been marked as possessing a high urbanization potential couldn't be constructed because of the existence of marked perimeters in immediate proximity, and because of having already reached the maximum number of constructed cells.

After having increased the scale of analysis and having reduced the cell surface to $20 \cdot 20 \mathrm{~m}^{2}$, we reach the minimal dimension set up for analysis, and the most exact one concerning the necessary estimates. 96 cells have been constructed on the West side of the township (Fig.5), even the cells with a low evaluation score, though not lower than 0.1 , having been included in the simulation, so as to get as close as possible to the proposed threshold. The average of the chosen cells' evaluations is of 0,264 . It represents 96

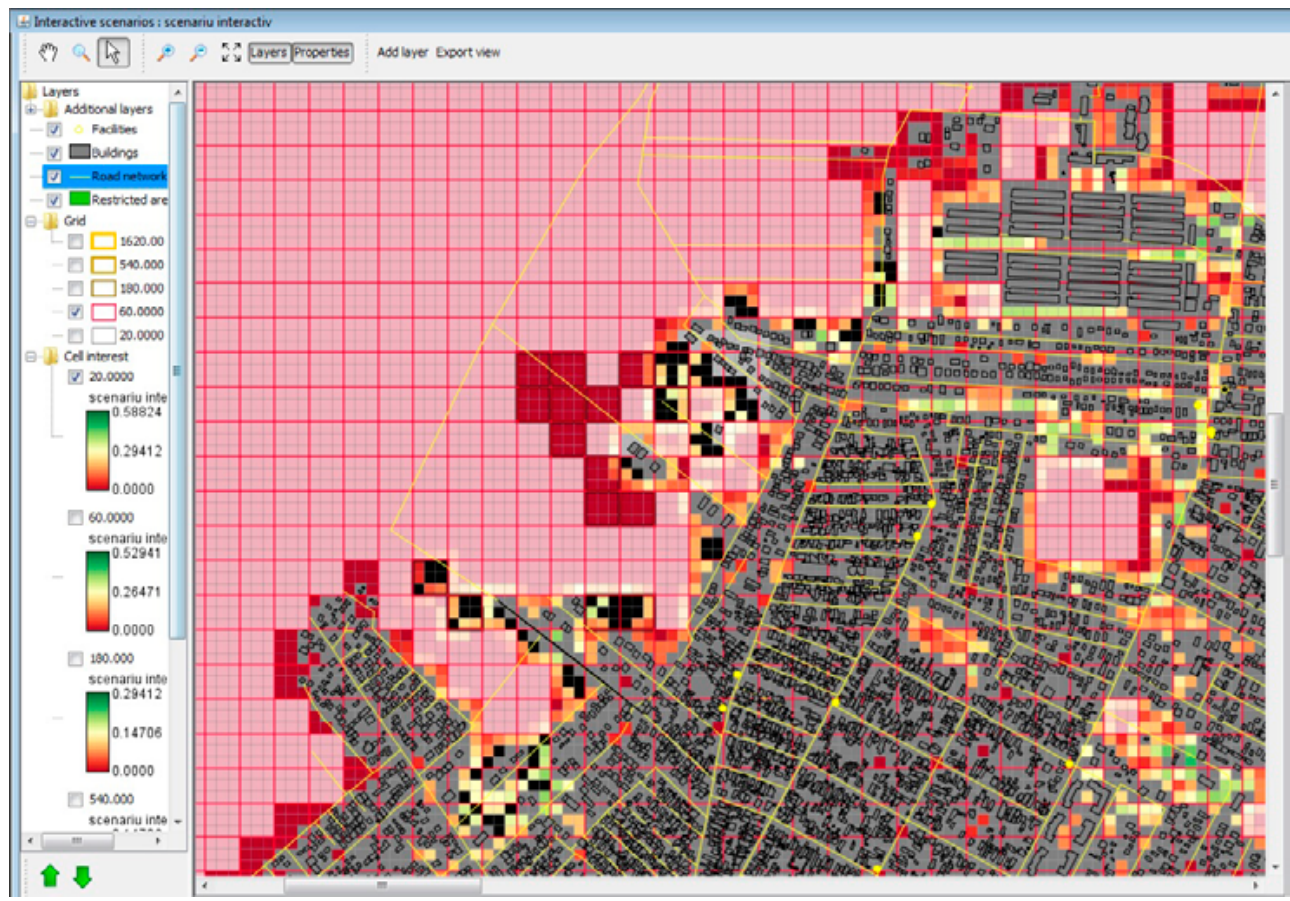

Figure 5. Identification of constructible cells given a cell size of $20 \cdot 20 \mathrm{~m}^{2}$, for a total sufrace area of $30,400 \mathrm{~m}^{2}$ 


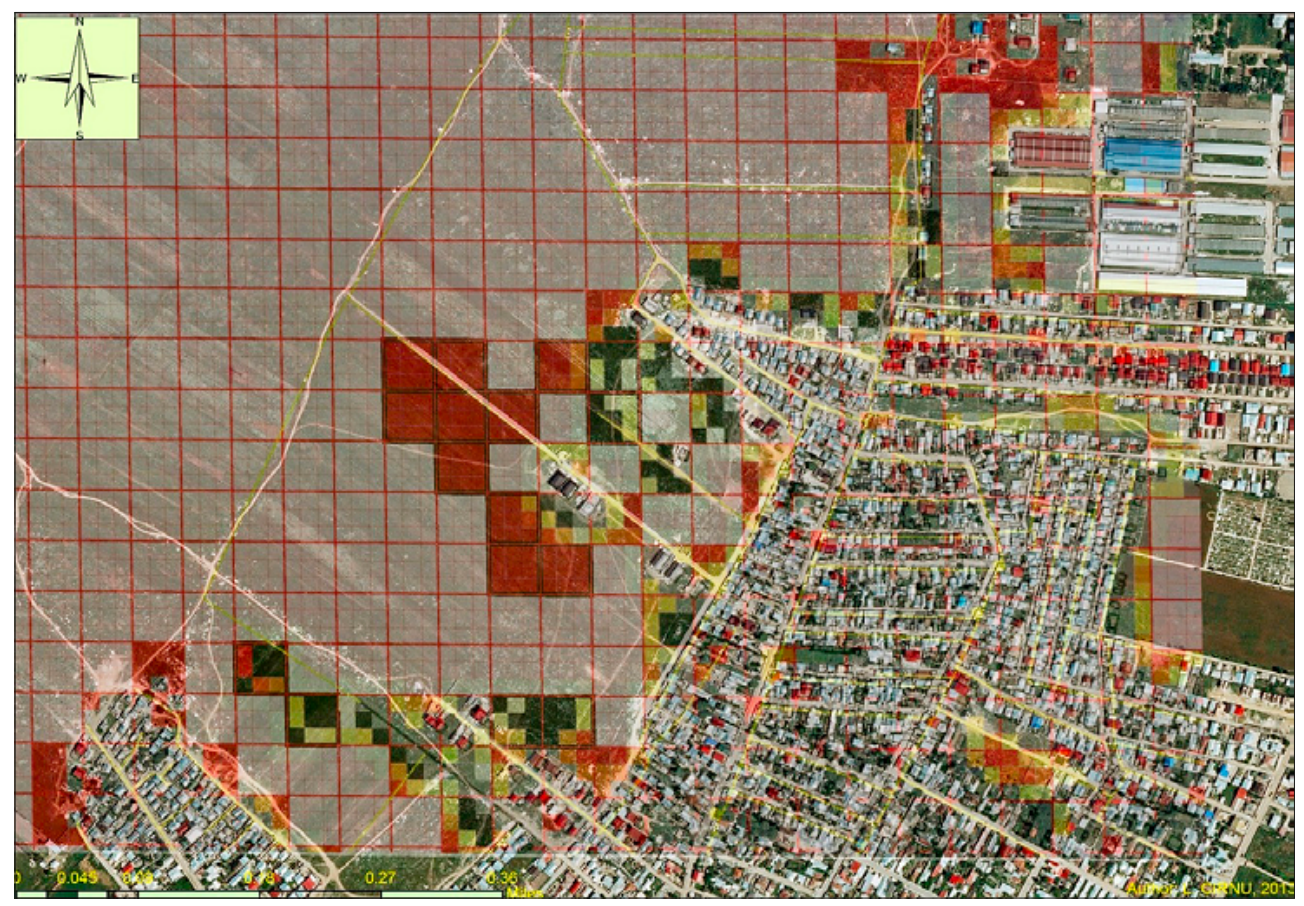

Figure 6. The superposition of cells with a high evaluation score and surfaces of $400 \mathrm{~m}^{2}$ onto the actual extant terrain

potentially constructed cells, representing a potential surface area of $38400 \mathrm{~m}^{2}$, a value which comes close to the proposed target.

Essential to this simulation is the fact that a fractal logic of spatial distribution of aggregates, with the preservation of areas meant to serve as green inroads, can only be achieved in the context of large-scale operations, rather than small-scope projects; the work allotments reveals itself as the solution most appropriate for achieving these aims.

By superposing the resulting model onto the actual terrain, one obtains a very clear image of the proposed extensions (Fig. 6), highlighted via black-coloured cells.

It is clearly noticeable that the areas put forward for urbanization are set in a pattern of continuity in relation to the built-up areas in 2010, so as to limit the squandering of the available land resource, while maintaining the essential element of this undertaking, namely the preservation of green inroads and the distribution of "vacui" and constructed aggregates in accordance with an internal hierarchy, as per a fractal logic (Cîrnu, 2014).

\section{CONCLUSION}

The fractal approach to the suburbs is more suitable to the realities of this type of urban fabric, characterized by the alternation of built-up and green areas. Moreover, this approach tries to provide a solution meant to reconcile the interests of the various categories of actors intending to produce a high-quality urban fabric. This proves to be a 
very difficult undertaking, given the (radically) different outlooks that these actors have upon the urban dynamics of townships, covering a wide range of positions between the public and the private purposes.

On a theoretical level, analyzing the points of view of each category of actors has yielded a potential solution, in the form of arranging these spaces according to the principles of a rational, sustainable development, via the implementation of the solution produced by MUP City.

The scenarios elaborated on the scale of the township of Pantelimon, or of a part of it, would allow the opening up to urbanization of new areas assigned a residential function, without contributing to the fragmentation of the urban fabric or to additional investments in terms of infrastructure, yet all the while protecting the extant green areas.

The essential condition for the practical implementation of such principles in Bucharest's perimeter remains, however, the establishment of a deciding body superior to local authorities, with the competence and objectivity required to manage residential development (and more) of the designated area in the direction of the general interest. Incorporating green areas into built-up urban fabric and the achievement of an effective interface between urban space and natural space are only possible on the level of large-scale real estate projects, conceived around a global perspective, encompassing a neighborhood or at a township level.

Although it is only theoretical, this approach provides a rational alternative to the current developmental trend in the suburbs of Bucharest.

\section{ACKNOWLEDGEMENTS}

The author expresses his gratitude towards Professor Pierre Frankhauser, who has displayed the patience and willingness of sharing the methods of fractal simulation during the training program hosted by the ThèMA laboratory, Université Franche Comté, Besançon, France

\section{REFERENCES}

Andersen, H. (2008). Why do residents want to leave deprived neighbourhoods? The importance of residents' subjective evaluations of their neighbourhood and its reputation. Journal of Housing and the Built Environment 23(2), 79-101.

Benevolo, L. (1994). History of the city (Histoire de la ville). translated from Italian into French by Catherine Peyre. Éd. Parenthèses, Marseille, 509 pp.

Berque A., Bonnin Ph., Ghorra-Gobin C. (2006). The unsustainable city (La ville insoutenable). Editions Belin, Paris, 366 pp.

Bolitzer, B., Netusil, N. R. (2000). The impact of open spaces on property values in Portland, Oregon. Journal of Environmental Management 59(3), 185-193.

Braubach, M. (2007). Residential conditions and their impact on residential environment satisfaction and health: results of the WHO large analysis and review of Euro- 
pean housing and health status (LARES) study. International Journal of Environment and Pollution 30(3-4), 384-403.

Castel, J.-C. (2007). From urban sprawl to urban fragmentation (De l'étalement urbain à l'émiettement urbain). Les Annales de la recherche urbaine. MEDAD, PUCA, Paris, 102, 89-96.

Cîrnu L. (2014). The physical expresion of the Bucharest urban sprawl (Formele de teritorializare ale exodului urban bucurestean), Editions Ars Docendi, Bucarest, 370 pp.

Cîrnu L. (2013).The fractal urban fabric. Emptiness as a urban planning item", Geopolitics, History, and International Relations, New York, Volume 5(1), 109-130.

Cîrnu L. (2013). "Dynamics of residential buildings in the Bucharest Metropolitain Area. An alternative to the inner city", Lucrarile Seminarului International "Dimitrie Cantemir", Editions of the Alexandru Ioan Cuza University, Iasi, No.35/2013, 85-93.

Frankhauser, P., Ansel, D. (2012). The decision to settle here or elsewhere (La décision d'habiter Ici ou Ailleurs). Editions Anthropos, Paris, 383 pp.

Frankhauser, P., Tannier, C., Vuidel, G., Houot, H. (2010). Une approche multi-échelle pour le développement résidentiel des nouveaux espaces urbains (A multi-scale approach for the residential development of the new urban areas). Modéliser la ville. Forme urbaine et politiques de transport. Editions Economica. Paris, 306-332.

Sieverts, T. (2003). Cities without cities: an interpretation of the Zwischenstadt. Spon Press Londo, New York, 187 pp.

Tannier, C. (2009). Optimal urban morphology, sustainable urban morphology. Approach in relations with the fractal city (Formes de villes optimales, formes de villes durables. Réflexions à partir de l'étude de la ville fractale). Espaces et sociétés 3(138), $153-172$.

Tannier, C., Vuidel, G., Frankhauser, P., Houot. H. (2010). Fractal simulations of the urban growth. MUP-city, a multi scale model for the new residential areas (Simulation fractale d'urbanisation. MUP-city, un modèle multi-échelle pour localiser de nouvelles implantations résidentielles). Revue internationale de géomatique 20(3/2010), 303-329.

Thomas, I., Frankhauser, P., Biernacki, C. (2008). The morphology of built-up landscapes in Wallonia (Belgium): A classification using fractal indices. Landscape and Urban Planning 84(2), 99-115. 